\title{
CONCEPTUAL SPHERE OF MODERN CINEMA (A STUDY OF HEADLINE COMPLEXES OF 21 ST - CENTURY EURopean AND ASIAN MOVIES)
}

\author{
Elena Gudeleva, Ekaterina Sudarkina \\ Vladimir State University, Russia
}

\begin{abstract}
This article aims to reveal the conceptual sphere of modern cinema discourse in Europe and Asia by analyzing movie headline complexes.

More than two thousand original movie titles and slogans of 21 st-century films presented at the largest festivals are studied. The main concepts (man, opposition, love, house and nature) are pointed out and explained. In addition to the detailed theoretical commentary, the paper shows how the cinema headline complex concentrates intertextual and non-textual associations, and carries information about authors' intentions and tastes of moviegoers who are the target audience for the interpreter.
\end{abstract}

Keywords: headline complex, concept, cinema discourse, translation, linguocultural analysis

\section{Introduction}

The headline complex (all the elements of the frame text grouped around a work's title $)^{1}$ takes on such functions as nominative, evaluative and expressive, informative, and advertising. It is aimed at helping people navigate in a large stream of data in a more flexible manner. The linguistic base in cinematography is a relatively new and regularly expanded section of onomastics. In Western science cinematographic names and other non-textual elements are studied within the terminological framework of the paratext theory formulated in the 1980 s by Gerard Genette and several other researchers (Robert Stam; Nicole Janin-Foucher) and also within the framing theory suggested by Erving Goffman (Frame Analysis, 1974) and Werner Wolf with the contributors to his anthology (2006), who have tried to apply it to media.

In Russia the headline complex of cinematic texts have so far received very little consideration. Movie titles (often called filmonyms), excluding other elements

\footnotetext{
1 According to N.A. Veselova (1998: 203) the headline complex includes all non-textual elements each of which can potentially interact with others and thus serve to create new meanings. P. Charaudeau (1997: 223) considers the headline complex (titraille) a genre per se and a subject of textual patterns; this term is also used by E.A. Lazareva, I.S. Guskova, A.V. Fatina, and A.Yu. Tseryulnik in their media text studies and by I.R. Galperina, T. Fedorova, and N.A. Konina in literature studies.
} 
encircling and framing the film, are studied primarily: Yu.N. Podymova (2006) investigates the structure and the functions of filmonyms, A.V. Antropova (2008) makes their comparative analysis, and E.V. Skvortsova (2011) employs terms of linguosynergetics in her study of feature film titles ${ }^{2}$.

Because there is no clear terminology with regard to movie titles and other framing elements of cinematic texts, it is necessary to look to areas outside cinematography such as interpretation and translation studies, linguistics, journalism, advertising, literature studies, etc.

Headline complex (header complex, headline set, sequence of headings and endings, header and final complex) is a literary term successfully used in Russian media text analysis. It includes a title, a slogan (advertising motto with a briefly formulated idea), a plot summary, the name of an author (director) or iconic actors, a poster, and audiovisual content (trailer). In this work we shall consider the linguistic base (the title and the tagline), while addressing the other elements when required.

Sometimes the term slogan or tagline is replaced in the film industry with such words as logline (a brief retelling of the plot in no more than two sentences made to catch the interest of potential viewers) or synopsis (a literary and informative retelling of the plot). We are sure that, because of its basic function and structure that can supplement the title, the term slogan expresses its current tasks to the fullest extent possible.

The study of headline complexes of cinematic texts is one of the techniques of exposing national conceptual spheres. We want to identify characteristic features in worldviews of different Asian and European countries by distinguishing typical global categories, keywords, metaphors, and images in the headline complex of their cinematography.

The concept considered as the basic unit of intercultural communication is an associative notion that replaces a series of images. Concepts can be described in several ways (Pimenova 2005: 15-19; Zhamsaranova 2011:33-47). In this work we shall treat the concept as a semantic formation that is characterized by specific linguocultural features and expresses the mentality of a linguistic persona from a particular ethnic

2 For deeper insight into different aspects of filmonyms see, e.g., Vorontsova, I.I. and N.L Tkachenko. 2015. Тенденции перевода фимьмонимов в контексте современного российского кинематографического рынка [Trends in Translating Movie Titles in the Context of Modern Russian Cinema Market]. Novyi filologichkii vestnik - New Philological Bulletin 3 (34): 139-149; Gorshkova, V.E. 2014. Название фильма как единица перевода и составмяющая образа-смысла [Film Title as a Unit of Translation and a Unit of ImageSense]. Vestnik PNIPU. Problemy âzykoznaniâ i pedagogiki 10: 26-37; Chaykisova, A.V. 2017. Национально-культурная специфика фильмонимов [Culture Specific Aspects of Film Titles]. Uspehi sovremennoj nauki 2 (2): 158-160; Rufova, E.V. 2017. Семантическая интерпретация фильмонимов на материале японского языка [Semantic Interpretation of Filmonyms (Based on Material in Japanese Language)]. Filologicheskie nauki. Voprosy teorii i praktiki 6-1 (72): $127-129$. 
community (according to Yu. S. Stepanov 2004: 42-67). The concept is a clump of culture that generates and, at the same time, is generated by it ${ }^{3}$.

Despite the fact that most films are co-produced, there is always one main country of production. The primary role of the author belongs to film script writing and direction. The author's worldview is formed under the influence of his/her national culture, and the output of his/her effort (film) later becomes part of this culture.

The difficulty of perceiving and studying foreign headline complexes is linked with the person of the interpreter who is the mediator between the author and the film's audience. In the course of decoding we observe the distortion of the producer's conceptual sphere, which is replaced in the mind of the bearer of another culture with his own worldview anyway. Some titles are interpreted with regard to audience's tastes and knowledge (experience): for example, the German film Elser (2015) by Oliver Hirschbiegel is known worldwide as 13 Minutes and in Russia as Взорвать Гитлера ('Blow Up Hitler'); the Icelandic film Fúsi (2015) by Dagur Kári revealing the image of a "little man" was released in Russia and some European countries as Virgin Mountain. Titles of Asian films are decoded in an equally liberal manner. For example, the South Korean film Gukjesijang (literally: 'The International Market') by Yoon Je-kyoon was released in some countries as Ode to My Father (2014). It has to be said that an absolutely logical characteristic of Russian moviegoers is their expectation of not only adequately translated titles of foreign films but also complete dubbing of their soundtracks as opposed to subtitling typical of European countries. In addition, each language has its own figures of speech and idiomatic phrases that make film interpreting more difficult. Here we shall try to use word forms that as close to general ideas of a cinematic text as possible, rely on both generally accepted and independent translations from European and Asian languages. Because of text volume limitations, we shall confine our study to the most vivid examples.

It should be noted that in different contexts one seme can be a structural part of several concepts at a time; therefore, the number of films in our sample will not match the number of concept-forming word usages. In order to optimize our estimations, we took account of title complexes of particular films with different concepts according to their number.

The relevance of the study consists in an attempt to describe the European and the Asian worldview by linguocultural analysis and highlighting concepts of headline complexes of European and Asian cinematic texts.

The subject matter of our research is headline complexes of films from Asian and European countries presented over the past 17 years at such international festivals as the Big Five (Cannes, Berlinale, Venice, Sundance, and Toronto) and two other venues

3 The national concept problem is presented in the study "Concepts As a Thin Cover of Civilization" (Stepanov 2007: 63). Stepanov notes that "concepts cannot be associated with any nationality (nationality by passport) in its general sense" and adds that "... a concept has its proper spirit expressed in a familiar and favorite mode of thought, and often by some person in one particular place, where people talk, watch, and listen..." 
- Karlovy Vary and Rotterdam. The essential criterion for classifying the films as made either in Europe or in Asia is the director's origin, followed by the main country of production for co-produced films, the theme and specifics of its presentation. The phenomenon of cultural androgyny is beyond the scope of our work and should be considered separately. We shall analyze 1506 titles (1069 titles of European films and 437 titles of Asian films) and 531 slogans for films from different genres.

The data are taken from several Internet sources such as the Internet Movie Database (IMDb.com) and KinoPoisk (kinopoisk.ru), which contain a vast collection of worldwide and national titles and other paratextual elements (taglines, posters, teasers, trailers, reviews). We also used official cites of international film festivals and online databases on information related to movies and film posters: CineMaterial (www.cinematerial.com), Кино MailRu (afisha.mail.ru), Iranian Movies (www.iranianmovies. com), Hong Kong and Korean movie databases (hkmdb.com,www.kmdb.or.kr), the streaming service MUBI (mubi.com). Moreover, we consulted experts at the Center of International Education of Vladimir State University, Regional Scientific Library, and Vladimir branches of Russian-Chinese House of Friendship and Cooperation, Federation of Jewish Communities of the CIS.

The basic research technique is linguocultural analysis, which makes it possible to solve the tasks formulated. The other research techniques we use are linguocognitive analysis, statistical technique, content analysis, and comparative analysis.

\section{From insights to titles and slogans}

Omri Ronen starts his article "Titles" by quoting from Curiouser and Curiouser: "Were it enquired of an ingenious writer what page of his work he had occasioned his most perplexity, he would often point to the title-page". Even the noted Russian writer Lev Tolstoy complained about the disability to invent names (Rohnen 2010). Nowadays various naming agencies design names for companies, brands and even titles for literary and cinematographic works. Nevertheless, directors and screenwriters try to come up with a title for their films by themselves.

S.D. Krzhizhanovsky (1931: 6) fairly said decades ago that every work of art "should rely on the capacity of its title": only a mnemonically made, painstakingly worked-out name provides the work of art and its meaning with some safety and recognition.

As shown by comparing movie titles in the Russian translation and in the original, the translation differs at times because of being focused primarily on the viewer's expectations. Usually, the title reflects the outlook of the authors and the country of production, and the word substitute distorts the perception of an alien reality.

It follows from academic and amateur film reviews of our days, starting with the criticism of the title, that moviegoers pay attention to the original version. For example: "What was the use of racking one's brains thinking out a title, if the original one suits best? Boż e skrawki - so the film is called in Polish, 'Edges of the Lord' - that's all: the translation matches the original meaning” (Erromango 2008). In the Russian 
version the film is known as $\Lambda$ ики смерти ('Faces of Death', 2001). The next example is Кандагap (2001) by Mohsen Makhmalbaf: "The original title of the film is Safar e Ghandehar, that means 'trip to Kandahar'. After all, there is no Kandahar in the movie but there's a journey is undertaken without any end...” (Kudryavtsev 2009).

There have been different studies with possible strategies of translating movie titles and slogans and film dubbing. In our opinion, the most complete classification of Russian cases has been suggested by Yu.N. Podymova (2006: 101): literal translation in different grammatical versions, transliteration, liberal translation, modulation, expansion, omission and mixed group. Relying on her model as the theoretical framework of this study, we managed to yield a relatively complete picture of translation strategies applied to our list of movie titles in Russian.

The range of translation strategies is given in Table 1 .

Table 1. Percentage shares of translation strategies applied to European and Asian titles in Russian

\begin{tabular}{|l|l|c|}
\hline № & Translation strategy & \% \\
\hline 1 & Literal translation & 61 \\
\hline 2 & Transliteration & 15 \\
\hline 3 & Liberal translation & 14 \\
\hline 4 & Modulation & 3 \\
\hline 5 & Expansion & 3 \\
\hline 6 & Omission & 2 \\
\hline 7 & Mixed group & 2 \\
\hline
\end{tabular}

Because of disparities in cultural paradigm and mismatch between sociocultural and historical associations of moviegoers, titles are sometimes subject to change. Thus, in the Russian-language announcements of the Cannes Film Festival the title of the French biopic by Michel Hazanavicius about Jean-Luc Godard, Le Redoutable (2017), was first presented as a literal translation from French - Грозныци ('redoubtable'), but was later renamed to Молодой Годар ('Young Godard') (see Ustiyan 2017).

Firstly, the associations with the word грозный among Russian viewers range from negative characteristics ('dreadful, frightening, fearsome') to toponyms (Grozny is the name of the capital of the Chechen Republic) and anthroponyms (Грозный is the nickname of the tsar Ivan IV - Ivan the Terrible). Secondly, substantivized adjectives as titles are not typical examples of Russian film naming conventions.

In this case the replacement of the literal translation (Le Redoutable) with the more liberal variant Молодой Годар does not lead to a change in the concept. On the contrary, the liberal translation of the title for the French film La tête haute (literally: 'standing tall') to Morodas кровь ('Young Blood') changes the semantic content of the concepts man and opposition. So, the original title is associated with the mental state of a person and expresses a protest against the circumstances, the adapted title is linked with the lexemes youth and rebellion. 
Thus, the dominance of literal translation among other strategies (shown in Table 1) indicates the intention to keep the idea of the film stated in the title.

Films are often accompanied by a slogan - a memorable phrase expressing the essence of the advertising appeal. Slogans have been used in film industry right from the start (Edwards 1985: 71) and are usually called taglines. Nowadays they are printed on posters and DVD covers, used in movie descriptions in Internet sources or even included in the trailer. The slogan is the most marginal and marginalized element of cinematic peritexts (Mahlknecht 2015: 414).

Nevertheless, not all modern films carry an advertising slogan. It is to a greater extent illustrative of European cinema, rather than Asian films. Usually, slogans gradually frame the film in the course of its release around the world. One film can be accompanied by up to 12 different variants of slogans on posters from different countries ${ }^{4}$.

In European cinema, slogans are found more often in films directed in France, Great Britain, Germany or with their participation. Slogans are mostly typical of dramas and thrillers.

In Asian cinema, the slogan is more typical of Japanese, Korean, Chinese and Israeli dramas, either social or psychological, or films containing elements of crime and action movies.

The taglines of both European and Asian films are unified in structure, vocabulary, and stylistics. The most typical tagline consists of no more than 3-6 words or 2-4 sentence-patterns with euphony, tropes and rhetorical figures used to increase attractiveness or give a condensed version of a plot: "Thunderclouds. Clouds of war. Spirit of the drum" (The Drummer, 2007); "Daring, Desirable, Dangerous" (Miss Lovely, 2012); "One girl. One car. One night. No coincidence" (Ramona, 2015), "Intoxicating dance of death!” (Thanatos, Drunk, 2015)5.

The amount of annotative slogans (74\%) is considerably higher than challenge slogans $(26 \%)$ : this ratio reveals the dominance of the informative function. The advertising and promotional function in taglines is expressed in vivid and emotionally loaded words: "One of the best five films of the year in the world" (The Cutoff Man, 2012); "The plot allows the viewer to discover the depth and attraction of the film's characters together with the peak of pleasure and entertainment" (The Drummer, 2007)

The concept is found in a relatively small number of slogans. Nevertheless, these slogans are the ones making it possible to expand the concept's semantic field or determine whether the movie title belongs to a specific concept, take e.g.: "Who is the most evil? Everybody. Resolved" (Outrage Beyond, 2012), "Let's kill each other today" (Battle Royale, 2000) - opposition; "When the rules don't fit, find the courage to follow

\footnotetext{
4 See 8 critics' picks on the poster for My Journey Through French Cinema (Voyage à travers le cinéma français, 2017) by Bertrand Tavernier at: http://www.imdb.com/title/tt5652594/ mediaviewer/rm3098095104, and 6 slogans for The Drummer (Zhan. gu, 2007) by Kenneth Bi at: https://st.kp.yandex.net/im/poster/2/5/8/kinopoisk.ru-Zhan-gu-2586878.jpg.

5 The translations from Asian posters were made by experts from above-stated organizations in Vladimir, Russia.
} 
your own" (Wadjda, 2012) - man, opposition; “The younger sister has a secret. Three discoveries are waiting for you” (Traces of Sin, 2016) - man, family.

\section{Conceptual sphere and headline complexes of Asian cinema}

All around the world Asian countries are associated with the specific mentality and unique cultures of the Orient. For all of their distinct features, all schools of Asian cinema have such traits in common as long takes of nature, play of colors, vivid images and details.

However, of all the 1506 motion pictures presented at the festivals under consideration, only 437 films have been made by directors from Asia. In $43 \%$ of the cases the expressive means used for nomination include metaphors, allegoric phrases, epithets, and other tropes. Not only do expressive means reveal specific thinking patterns, but they also allow expanding the semantic field of a concept. Titles of Asian films often contain references to different colors, especially red and its tints: Bride of Fire (Arous-e atash), 2000; Warm Water Under a Red Bridge (Akai hashi no shita no nurui mizu), 2001; About the Pink Sky (Momoiro sora o), 2011; Black Coal, Thin Ice (Chinese: Bai ri yan huo; literally: 'Daylight Fireworks'), 2014; Tel Aviv on Fire, $2017^{6}$.

In addition, the words used in Asian film titles often carry abstract or positive meanings and refer to natural cycles: The Season of Guava (Mùa oi), 2000; Comrade (Hebrew: Bekarov, Yikre Lekha Mashehu Tov, literally: 'Something good will happen to you soon'), 2006; Have a Nice Day (Chinese: Hao ji le; literally: 'Wonderful'), 2014; Free and Easy (Qinsong+yukuai), 2017. This is generally not typical of the approach to dramaturgy and conflicts used in the West, where "nobody will go to the movies or turn on the TV just to watch such a film as, e.g., The Village of the Wonderful and Joyful" (Walter 1993: 26).

The dominant concepts and their components distinguished by our analysis of headline complexes of Asian films are house, opposition, nature, man, and several other ontological, cultural, and value dominants (time, creation, feelings, life, motion). The intensity of lexical expression of these concepts within the groups is roughly the same.

The concept of house is included in the megaconcept of space, which is a basic ontological category, and the dimension of the world (19\% out of the $36 \%$ falling to the share of space). The house reproduces the structure of the universe. The distinct feature of its representation is that the key components included in the concept's associative field, i.e., family, parents, children, generation ties, forgiveness, overcoming, respect, tradition, are closely correlated with each other and express the general idea of family and home among Asian peoples: Daughter from Yan'an (Enan no musume), 2002; "The family that eats together stays together" (Noriko's Dinner Table, 2005); The Paternal House (Khaneh Pedari), 2012; Like Father, Like Son (Soshite chichi ni naru), 2013; Little

6 In most cases we introduce a worldwide (English) title, transliterated original title (in brackets) and give its literal translation only if the semantic aspect is important for our interpretation. Slogans from film posters are given in English. 
Brother (Bauyr), 2013, The Little House (Chiisai Ouchi), 2014. "My secret is hidden in this little house" (The Little House, 2014)

Without the specified notions the house is empty: 3-Iron (Hangul: Bin-jip; literally: 'Empty House'), 2004; Fill the Void (Lemale et ha'halal), 2012; House of Others (Skhvisi sakhli), 2016; it becomes "the space in which past, present and future mix in the chronicle of separation” (storyline for Greenland, 2014).

As a rule, names and nicknames of children in family-related headline complexes carry an underlying idea. In the film directed by Raşit Çelikezer in 2011, Can (pronounced as ['dzän]) is not merely the name of a foster son illegally purchased by a young Turkish family. In Persian, Tajik, Armenian, Azerbaijan, Turkish, and some other Indo-European and Turkic languages -jan- means 'spirit, life, dear, heart'; it can be used both as a separate word and as a suffix or ending of generic names to express the speaker's affection for the person indicated. The meaning of the name Can becomes the focal point of the drama: the mother neither loves nor accepts the purchased little one called Can. Anna Bielak (2012) considers the resonation of the title with the English meaning of the word and finds one more level of understanding the idea of the Turkish film.

The Israeli drama Princess (working title New Family, 2014) is a case of atypical family situation. Holly is a 12-year-old girl who has become an object of unambiguous attention for her stepfather. Her psychological condition is graphically emphasized in the film's poster, on which we find the word prince hidden in PrinceSs as the key to the film's meaning.

The concept of opposition is expressed in the considered films in such binary pairs as man vs. society (system); man vs. man, and man vs. circumstances. Such pairs typical of European movie titles as man vs. nature, life vs. death, and love vs. hate are virtually absent. The concept of opposition covers such notions as choice, war, and rebellion.

Of course, films about warfare and criminal affairs are typical products of the global movie industry. Nonetheless, Asian films carry less striking titles than their European counterparts. Usually, titles and slogans point to a character or a group of characters: Hero (Ying xiong), 2002; Oldboy (Oldeuboi), 2003; Ghost in the Shell 2 Innocence, 2004; Tai Chi Hero, 2012. In other cases titles and slogans give only a hint that the film is about warfare: Battle Royale (Batoru rowaiaru), 2000; The Coast Guard (Hangul: Hae anseon, literally: 'The Coastline'), 2002; Joint Security Area, 2004; "Who will be the last man standing? / An epic tale of blood, lust and greed" (Sukiyaki Western Django, 2007); "Through the tank sight..." (Lebanon, 2009); Shield of Straw, 2013; Paradise in Service (Jun zhong le yuan), 2014.

As shown by the analysis of the sample, the concept of opposition also includes lexical units with such meanings as play, frontier, and creation: Secret Ballot (Ra'ye makhfi), 2001; The Drummer (Zhan.gu), 2007; Five Broken Cameras, 2011; Tai Chi 0, 2012; Closed Curtain (Persian: Pardeh; literally: 'Curtain'), 2013; Manuscripts Don't Burn (Dast-Neveshtehaa Nemisoozand), 2013; Liar's Dice, 2013; Red Amnesia (Chinese: Chuang ru zhe, literally: 'The Intruder'), 2014, The Six-Day War, Uncut (Censored Voices, 
2015); The Wedding Plan (Hebrew: Laavor Et Hakir; literally: 'Go Through the Wall'), 2016.

Nonetheless, the lexeme of creation can be viewed as a specific concept, in which folklore traditions and ideas of modern art are conveyed separately or in a synthesized form: "This is your brain on anime" (Papurika, 2006); Butter Lamp (Sūyóu Dēng), 2013; Blind Massage (Tui Na), 2014; Tales (Ghesse-ha), 2014; A Dragon Arrives! (Ejdeha Vared Mishavad! - an allusion to films featuring Bruce Lee), 2016. In the short film Bansulli made in Nepal (2012) the flute is not merely an instrument that the main character plays; its sound is a sign of hope, a metaphor of the people's voice.

Nature is one of the key and most multifarious concepts of Asian cinema. Asian movie titles often contain such words as sun, moon, earth, sky, and derived figurative comparisons: The Vertical Ray of Sun (Mùa hè chieu thang dung), 2000; Daughters of the Sun (Dakhtaran-e khorshid), 2001; Chongqing Blues (Chinese: Rizhao Chongqing; literally: 'Sunshine over Chongqing'), 2010; Wu Tu: My Land, 2015.

The concept of nature also covers the world of flora and fauna: Stray Dogs (Sag-haye velgard), 2004; The Butterflies Are Just a Step Behind (Parvaneha badraghe mikonand), 2004; Three Monkeys (Üç Maymun), 2008; Black Mulberry (Shavi Tuta), 2014; The Taste of Betel Nut (Bing Lang Xue), 2017.

The drama of human and social relations is expressed via natural objects and phenomena mentioned in film titles: Potato (Jiseul, 2013) is a symbol of survival; Caterpillar (Kyatapirā, 2010) is embodied in the tragic image of a Japanese soldier who lost all four limbs and his hearing; Sarmaşık (Ivy, 2015) becomes a political allegory; Sand Storm (Sufat Chol, 2016) describes Bedouin women's struggle for changing the unchangeable rules.

The abundance of such titles means that nature has a special niche in Asian cinema discourse. Nature hides a mystery; it attracts film directors and characterizes the main line in the culture and philosophy of the Orient, i.e., integration of man and nature in an organic unity.

The concept of nature also includes such lexical units as change, plastic, machines. They expose the world's entropy algorithm of development, socioeconomic and environmental relations. In Still Life (Chinese: Sanxia Xaoren, literally: 'Good people of the Three Gorges', 2006) the fantastic landscapes of China are shown together with the brutal imagery of artificial structures; Three Gorges is a hydroelectric dam on the Yangtze River. A River Changes Course (2013) is the story of several families from modern Cambodia who try building a new life. Plastic China (2016) presents the frank imagery of plasticscapes and ruined destinies.

The reference to man is typical of both dominant and secondary concepts ( $16 \%$ of concept representatives, $7 \%$ of which contain a proper name). Therefore, we describe it both as a separate category and together with other cultural and existential dominants. Man gets involved in a cyclic model of time that is manifested in the infinite flow of life and alternation of generations.

In this regard, an interesting aspect of describing a worldview is that the idea of 
motion in headline complexes is generally associated with reaching the frontier or with a comeback: Welcome to Destination Shanghai (Mu di di Shanghai), 2003; The Last Step (Pele Akher), 2014; The Return to Homs, 2014 "You either win or lose, it depends on half a step" (Weeds on Fire, 2016). Time is associated with a period or a cycle of life: The Circle (Dayareh), 2000; Spring, Summer, Fall, Winter... and Spring (Bom yeoreum gyeol guerigo bom ), 2003; "Extraordinary days and days that are strikingly alike" (About the Pink Sky, 2011); Thanatos, Drunk (Chinese: Zui sheng meng si; literally: 'Live for Today'), 2015; The Wasted Times (Chinese: Luomandike xiaowang shi, literally: 'The Story of the Death of Romance'), 2016.

Love is included in the concept of feelings. Despite the fact that there have been many vivid interpretations of Eros in the literary and philosophical traditions of the Orient, the concept of love is represented in a relatively small number of movie titles and slogans: "The hope, one day, to be able to love" (This Charming Girl, 2004); "Love always finds a way" (Tuya's Marriage, 2006); Like Someone in Love, 2012; What They Don't Talk About When They Talk About Love (Yang tidak dibicarakan ketika membicarakan cinta), 2013; Pleasure. Love, 2016. However, almost every film contains a love story.

Whereas in the West love is associated with a romantic paradigm and the philosophy of new corporeality, in the East love is a form of spiritual experience articulated in the ideological content of cinematic text: "Before Time rushes forward, measure carefully the essentials of love once again" (In the Mood for Love, 2000); "What will lighten our dark night? An untimely love?!" (Tales, 2014).

One of the main problems with grasping headline complexes of Asian films is that titles of certain films are translated by means of transliteration. This method has been used in 57 of the 437 films (13\%).

We decided to conduct an experiment and offered 15 native speakers of Hebrew, Farsi, and Chinese aged 18 to 45 , as well as 15 respondents from Russia, to share their associations with the following words used in movie titles:

Kedma (Hebrew: המדקה). The root $k-d-m$ comes from Semitic languages and means a geographic direction (front, ahead, eastward; the ancient name of the Dead Sea is the Eastern Sea or Kedma; kidma is a noun for progress, and kadam is a verb for be ahead; see IRIS, המדק). The film made by Amos Gitai (2002) is a historical drama based on a true conflict between Jewish refugees and Palestinians that occurred right before the foundation of the State of Israel. On May 7, 1948 a group of Jewish refugees from Europe who had survived the horrors of concentration camps reached the Palestinian shore onboard the cargo ship Kedma.

Lantouri (sروتنال) is a Persian slang word that refers to a cheap, liable or unworthy person; it comes from the times of first casinos in Iran using kerosene lamps with mantels (lantouri denotes such a lantern, too); a loser unable to pay for loss had to carry a lantern for a winner anywhere (s)he goes and was also named lantouri. In the mocumentary by Reza Dormishian (2016) Lantouri is the name of a street gang founded by Pasha to target those in Tehran who prospered in society through corruption. The title sheds light on sore spots of modern society; it helps to reveal Pasha's 
true nature in a shocking history with journalist Maryam, who rejects the advances of Pasha. He attacks her with acids; Maryam, a former fighter against lex talionis, seeks revenge herself: an eye for an eye.

Behemoth is the international metaphorical name of the film by Zhiao Liang (2015) about the unbearable environment of Chinese coal and steelmaking plants in the region of Inner Mongolia. In Classical Hebrew b'hemoth is the plural of b'hemah meaning 'beast'. The word has different cultural connotations: from power and fertility (see Cirlot 2010: 116) to the biblical monster mentioned in the OT alongside Leviathan (Job 40:10-19) and the huge demon from Dante's Divine Comedy. In Russian the words behemoth and hippopotamus are doublets. In modern English behemoth is used for any huge object (OALD). The Chinese title for the movie printed on poster is 悲兮魔兽 (pinyin: bēixì móshòu), which could be translated as 'the monster that brings sadness'.

Table 2. Examples of associations in a descending order of popularity

\begin{tabular}{|l|l|l|}
\hline Name & $\begin{array}{l}\text { Associations of Russian respon- } \\
\text { dents }\end{array}$ & Native speakers' associations \\
\hline Kedma & Clothes & Progress \\
& Food & Novelty \\
& Organization & Money \\
& Woman's name & Ahead \\
& Actress & Earth \\
& Old woman & New job \\
\hline Lantouri & Female name & Liar \\
& Ancient lineage & Unworthy \\
& Country & Swear \\
& Totemic animal & Lantern \\
& Flower & Unreliable \\
& Dance & Criminals \\
\hline Behemoth & Animal & Ugly \\
& Big & Aesthetically unsavory \\
& Fat & Huge \\
& Obesity problem & Fat \\
& Ecology & Awkward \\
& Animal's nickname & Calm \\
\hline
\end{tabular}

It follows from this table (Table 2) that Russian viewers associate the name Kedma most often with a personal name. They attribute positive images and proper names to the name Lantouri (flower, dance, woman); however, Persians classify this name as a slang word with negative semantics.

The etymology of the name Behemoth that expresses the director's view of the impact of industrialization is unfamiliar to the Russian viewer. It is interesting that in France and Germany the film's name is rendered as Behemoth the Black Dragon, whereas 
Russian critics specify that Behemoth is Chinese Leviathan (see South China Insight News 2016).

It follows from the survey that the perception of film titles is affected by differences in culture, outside world, religion, basic and background knowledge. These factors also predefine expectations from film screening, and a film's content does not always correspond to first impressions.

\section{Conceptual sphere and headline complexes of European cinema}

Most of the films presented at the film festivals we considered have been made in Europe. It has a universal culture with such distinctive features as diversity and integrity. European culture is divided into unique and distinctive periods; however, its basic principles, i.e., person and personal freedom, remain unchanged. The deliberate contemplation of the flow of life is not a typical feature of European cinema as opposed to Asian cinema. The focal points of European films are conflict events and situations, everything that can rock one's world and change one's destiny.

Man is the central idea of any culture. It is exactly in European cinema where man becomes an object of close attention, which points to the constant interest in his individuality, peculiarities, and destiny. The concept of man is mentioned in $50.2 \%$ of the titles and slogans of the studied films. The slogan of the joint Belgian-French movie Superstar (2012), "Who are you?", can be considered the concept's main question. The lexeme of man is a meganconcept, i.e., it has a multifarious content.

First of all, man is a name. Thirty-one per cent of European headline complexes expressing the concept of man refer to the name of an extremely popular person or a film character. Selecting a name is like selecting an invariable cultural fact and a key cultural principle; names are biographically and historically remarkable (Florenskij 2009: 135, 156). The name of a renowned person allows the viewer to immediately coin various respective associations: for example, The Extraordinary Life of Edith Piaf (La môme, 2007) is associated with France, music and variety art; Mr. Turner (2014) is associated with Britain and painting, and Pasolini (2014) is associated with Italy, cinema and challenge. Sometimes, however, initial name-related associations can be false: for example, Dormant Beauty (Bella Addormentata, 2012) is a mere metaphor because the film is about euthanasia against the backdrop of the last six days in the life of a woman in a coma; A Kalashnikov Thought (Un pensiero Kalasnikov, 2013) contains a Russian surname associated worldwide with weapons. In this case the director is consciously provocative and thus produces new, deeper associations.

In addition, the semantic field of the concept of man includes lexemes that refer to the following:

- physical, intrinsic traits, spiritual world: Bastards (Les Salauds), 2013; L'intrepido (Italian for Fearless), 2013; Black Souls (Anime nere), 2014; The Girl Without Hands (La Jeune Fille sans mains), 2016;

- sex and age: Young and Beautiful (Jeune et Jolie), 2013; Li'l Quinquin (P'tit 
Quinquin), 2014; Jeannette: The Childhood of Joan of Arc (Jeannette, l'enfance de Jeanne d'Arc), 2017;

- kinship: It Was the Son (E stato il figlio), 2012; Blood of My Blood (Sangue del mio sangue), 2014; My Mother (Mia madre), 2015;

- actions directed at or taken by people: Gabber Lover, 2016; A Prayer Before Dawn, 2017; Los Desheredados (Spanish for Disinherited), 2017;

- characters identified as members of a social or trade community: People of the World (Les Gens du Monde), 2014; I am a Soldier (Je suis un soldat), 2015; Robinù, 2015; Personal Shopper, 2016.

European cinema is personality-centered; even the destiny of a most ordinary man raises an increased interest. A distinctive feature of European cinema is that it pays greater attention to women than Asian cinema: $42 \%$ of headline complexes including references to a name or sex are dedicated to women: Women Who Run Hollywood (Et la femme créa Hollywood), 2016; Bernadette Lafont, and God Created the Free Woman (Bernadette Lafont et Dieu créa la femme libre), 2016. The woman is an inspiration, an intrigue, a creatrix.

Another peculiarity of European films is the manner in which they present teenage characters: the teenager has an undoubtedly strong personality; he keeps on fighting when the adults around him have given up; he takes responsibility for his decisions while still remaining a child. That is why the lexeme teenager is classified as diverging. In some films teenage characters are described in positive words symbolizing dreams of youth: take, e.g., Pretty Butterflies (Bellas Mariposas), 2012; Cherries (Trešnje), 2017. In other movies, these characters are described in negative terms and the viewer understands that the teenager is a personality ready to fight for his freedom: e.g., Misunderstood (Incompresa), 2014; Handful of Stones (Kamen u ruci), 2017; Bloody Milk (Petit Paysan), 2017. The lexeme teenager is basically associated with challenge and rebellion: e.g., the slogans "A joyous, heart-swelling story of youthful rebellion" and "Three Girls vs. The World" of the film We Are the Best! (Vi är bäst!), 2013. It is interesting that in European cinema the house and its parts can symbolize opposition within the family: Balcony (Ballkoni), 2013.

Opposition lies at the heart of human nature. This concept is structurally complex: opposition may be manifested in three scenarios (ego vs. alter ego, me vs. alien me, me vs. the world).

The ego-alter ago line is about fighting oneself, one's own feelings and circumstances: e.g., The Past (Le Passé), 2013; One More Time With Feeling, 2016. However, a fight against circumstances gives rise to inspiration (Staying Vertical (Rester Vertical), 2016); that is why the structure of opposition includes such concepts as creation and art: e.g., Living Still Life (La résurrection des natures mortes), 2012; The Dancer (La Danseuse), 2016.

The ego vs. alien ego line is manifested in the opposition of man vs. man, e.g., Freud vs. Jung. Interpersonal struggle gives rise to animal instincts and gets people living on the edge: e.g., "We can all lose control" (Wild Tales (Relatos salvajes), 2013); "A beast 
hides in everyone. Do not wake it up" (The Beast (Zvir), 2016); Wild Horses, 2016; 120 Beats per Minute (120 battements par minute), 2016. The struggle between person and person is associated with rejects and rejection (Trash (Poubelle), 2016), and factors that kill relationships: in Frost (2017) a trip to the war zone in Ukraine leads to a war within a young couple.

Gender-based struggle is another type of conflict. In the world depicted in European cinema men and women live by themselves: e.g., The Last Resort (L'ultima spiaggia), 2016; Superbia (literally: 'vanity, disdain'), 2016.

Sometimes, a conflict is expressed at the level of morphology via the imperative mood or contraposition. The release from opposition is outlined by the film director who marks sore spots of modern society: e.g., Don't Be Bad (Non essere cattivo, 2015); "Because a plate of Gulash tastes better with company" (Fine (Dobro), 2016).

The me-against-the-world scenario is manifested in the opposition between man and nature: e.g., The Fifth Season (La Cinequieme Saison), 2012; Force Majeure (swedish: Turist), 2014; "A bereaved headmaster fights a crocodile" (Crocodile, 2014). The opposition between man and society always leads to blood spilling, cruelty, conflicts, collisions, battles, wars, and revolutions: e.g., Peshmerga, 2016; Assalto al Cielo (Italian for Assault against the Skies), 2016; After the War (Après la guerre), 2016; Fight on a Swedish Beach!!!, 2016; After School Knife Fight, 2017; Real Gods Require Blood, 2017; A Violent Life (Une vie violente), 2017.

All concepts have an open structure. For example, the concept of opposition has absorbed such lexemes as refugee and path. People run away from political struggle but get involved in social conflicts, e.g., in The Human Cargo (La Nave Dolce), 2012; Cockaigne (2012), where Cockaigne is the name for a legendary land of plenty and, at the same time, the poorest part of London; Happy End, 2016, Sea Sorrow, 2016; The Refugees (Refugiado), 2014; If I Had It My Way I Would Never Leave, 2017. This opposition is expressed symbolically; however, even film titles arousing positive emotions still carry some bitter irony.

The concept of love is more diverse and controversial than in Oriental cinema. In films love is expressed, first of all, in the form of relations, a connection between two people; that is why, the concept's structure includes such polar lexemes as encounter and break-up: e.g., A Special Day (Un giorno speciale), 2012; After Love (L'Economie du Couple), 2016.

On the one hand, people dream about romantic love, faith and romantic places: e.g., Paradise: Love (Paradies: Liebe), 2012; From the Land of the Moon (Mal de pierres), 2016; Pure Hearts (Cuori Puri), 2017. The character is ready to fight for happiness, love, and be loved; that is why, he is shown as a fighter: Something in the Air (Apres mai), 2012; "There is no need for words when love and hate are at stake" (The Tribe (Племя), 2014). At first sight, the title of the film Sicilian Ghost Story (2017) does not contain any trace of romance. Sicilian stories are associated with Italy, passion and mafia but this movie is an allusion to the Orpheus and Eurydice of today: the difference between 
the film and the ancient legend is that in the former it is a girl of 13 who walks into the dark world after her beloved.

On the other hand, love is associated with passion: e.g., Signs of Passion (Petites coupures), 2003; "Passion knows no obstacles" (Stranger by the Lake (L'Inconnu du lac), 2013); My King (Mon roi), 2015. Human vehemence and impetuosity bring physiological issues to the forefront, and love is understood as sex: Intimacy, 2016; The Virgin Soldier (Le Soldat vierge), 2016; In Bed with Victoria (Victoria), 2016; Amant Double (L'Amant Double), 2017; Lover for a Day (L'Amant d'un Jour), 2017.

Passion often goes side by side with jealousy, betrayal, danger and love triangle: e.g. "Dangerous flirting, killing passion" (A Bigger Splash, 2015); Two Youths Died (Deux Égarés sont morts), 2017; "One woman, three loves, and the magic of tango" (Tango Libre, 2012), Ismael's Ghosts (Les fantômes d'Ismaël), 2017; "Un foudroyant triangle amoureux" (French for 'a life-changing love triangle') - slogan for Three Hearts (3 coeurs), 2014. It is interesting that betrayal is not always seen as treason and is sometimes presented as an example of freedom of choice: "No backstabbing. Just business" (Passion, 2012); "Pure, simple and heartbreaking in its playing out, moment by moment, of love and betrayal” (Jealousy (La Jalousie), 2013).

In European cinema love is often shown as destructive but the desire for experiencing this feeling is often stronger than one's will: it makes people active, change the world around and, therefore, live. Love makes people beautiful: e.g., Let the Sunshine In (Un beau soleil intérieur), 2017; Love Is All You Need (Danish: Den Skaldede Frisør, literally: 'The Bald Hairdresser'), 2012, a film whose original title contains an oxymoron and the translated title directly refers to a song by The Beatles.

It should be noted that all of the three considered concepts are interdependent; therefore, one headline complex may point to several concepts at once. For example, the film I, Daniel Blake (2016) reflects the combination of man and opposition by syntactic means; Blood Father (2016) with the slogan "A Father Makes His Own Justice", Graduation (Bacalaureat, 2016) with the slogan "A father will do anything to save his daughter's future" points at the combination of man + opposition + love.

\section{Conclusion}

The headline complex is a synthesis of a language base, literary images, and related associations linked with a work of art. It is the associative center of a cinematic text, a condensed expression of the film's key idea, and reflects the moral and spiritual state of the society, the profile of human consciousness, and national conceptual sphere.

Slogans are not obligatory components of the headline complex but they play an important role in vectoring viewers' associations; slogans may expand the semantic field of a concept or point out whether the movie title belongs to a specific concept.

Distinctive features of national cinema are discovered by headline complex studies.

The main concepts of Asian films are house, nature, opposition, and man. The headline complex of modern Asian cinema is characterized by vivid phrases and expressive 
figures of speech such as personification, metaphor, anaphora, metonymy, etc. Asian directors try not to use provocative words and images included in such concepts as war, sex, violence, and cruelty; they are more often inclined to use notions arousing positive emotions. The main obstacles for Russians who try to understand Asian cinema consist in cultural and background knowledge differences.

The main concepts of European films are man, opposition, and love. The headline complex of European films is not characterized as provocative either. Its main distinctive features are diversity of opinions, individuality, and freedom of expression. As a rule, Europeans try not to name their films in a manner shockingly explicit for the viewer. When explicit topics are covered in the film content itself, they are merely hinted at in the headline complex.

In our opinion, a major difference between Asian and European cinema is that the former is oriented at showing the life of a person within society and promotes the philosophy of life and spirit; consequently, people value each moment of their lives, they act unhurriedly and intuitively.

In European cinema the individual declares his exceptionality, values his privacy and yet remains part of the society, which is a manifestation of materialism and careful calculation.

Asian cinema is essentially contemplative, which accounts for extensive use of metaphors: they are a way of getting to know the world and forming a holistic worldview. European cinema makes more extensive use of various symbols; that is why European films are characterized by polar presentation of concepts and attention to detail.

\section{References}

Antropova, A.V. 2008. Названия американских, английских и российских кинофильмов: сопоставительная характеристика и проблемы перевода [Titles of American, English and Russian movies: comparative characteristics and problems of translation]. $\mathrm{PhD}$ diss., Ural State Pedagogical University, Ekaterinburg.

Bielak, A. 2012. Can. Sundance Film Festival 2012. Smells Like Screen Spirit, January 31. http:// smellslikescreenspirit.com/2012/01/can-review/ (accessed August 6, 2017).

Charaudeau, P. 1997. Le discours d'information médiatique. La construction du miroir social. Paris: Nathan "Médias-Recherches".

Cirlot, J.E. 2010. Словарь символов [Dictionary of symbols]. Fedor S. Kapica, T. Kolyadich (trans.). Moscow: ZAO Tsentrpoligraf.

Edwards, G.J. 1985. The International Film Poster. Salem, NH: Salem House.

Erromango. 2008. Не верно подобрано название фильма - это слабо сказано... [Putting it mildly, the film's title is far from appropriate]. KinoPoisk.Ru, February 14. https://www.kinopoisk.ru/film/14851/; https://www.kinopoisk.ru/user/147709/comments/ (accessed August 6, 2017).

Florenskij, Р. 2009. Иконостас. Имена [Iconostasis. Names]. Moscow: AST.

Genette, G. 1997. Paratexts; Thresholds of Interpretation. Jane E. Lewin (trans.). Cambridge: Cambridge University Press. 
Goffman, E. 1986. Frame Analysis: An Essay on the Organization of Experience. Boston: Northeastern University Press.

IRIS - Big Hebrew-Russian and Russian-Hebrew dictionary by Dr. Baruch Podolsky, המדק. http:// www.slovar.co.il/translate.php (accessed August 6, 2017).

Krzhizhanovskiy S.D. 1931. Поэтика заглавий [Poetics of titles]. Moscow: Nikitinskie Subbotniki.

Kudryavtsev, S. 2009. Реальная притча [Realistic parable]. KinoPoisk.Ru, March 17. https:// www.kinopoisk.ru/review/909995/ (accessed August 6, 2017).

Mahlknecht, J. 2015. Three Words to Tell a Story: the Movie Poster Tagline. Word \& Image 31 (4): 414-424.

OALD - Oxford Advanced Learner's Dictionary, Behemoth. http://www.oxfordlearnersdictionaries.com/definition/english/behemoth?q=behemoth (accessed August 6, 2017).

Pimenova, M.V. 2005. Методология концептуальных исследований [Methodology for conceptual research]. In Antologiya Kontseptov. Vol 1., V.I. Karasik, I.A. Sternin (eds.), 15-19. Volgograd: Paradigma.

Podymova, Yu.N. 2006. Названия фильмов в структурно-семантическом и функциональнопрагматическом аспектах [The titles of movies in structurally-semantic and functionally-pragmatic aspects]. PhD diss., Adygea State University, Maikop.

Ronen, Omry. 2010.Заглавия [Titles].Zvezda, vol3.http://magazines.russ.ru/zvezda/2010/3/ ro14.html (accessed August 6, 2017).

Skvortsova, E.V. 2011. Аинамика номинативной парадигмы американских художественных фильмов [Dynamics of the nominative paradigm in American feature films]. PhD diss., Samara State University, Samara.

Slobodyanyuk, E.P. 2008. Настольная книга копирайтера [Copywriter's handbook]. Moscow: Vershina.

Stepanov, Yu.S. 2004. Константы: Словарь русской культуры [Konstantyi: Slovar russkoy kulturyi]. 3rd Ed. Moscow: Akad. proekt.

Stepanov, Yu.S. 2007. Концепты. Тонкал пленка цивилизации [Concepts. A thin film of civilizations]. Moscow: Yazyiki slavyanskih kultur.

Ustiyan, G. 2017. “Кроткая” и “Грозный”: 13 главных фильмов Каннского кинофестиваля 2017 [A Gentle Creature and Redoubtable: 13 KeyFilms of The Cannes Festival-2017].Harper's Bazaar, April 12. http://bazaar.ru/bazaar-art/kino/krotkaya-i-groznyy-13-glavnyh-filmov-kannskogo-kinofestivalya-2017/ (accessed August 6, 2017).

Veselova, N.A. 1998. Заглавие митературно-художественного текста: онтология и поэтика [Ontology and poetics of literary text titles]. PhD diss., Tver State University, Tver.

Wolf, W. 2006. Framing Borders in Literature and Other Media, W. Wolf and W. Bernhart (eds.). Amsterdam/ New York: Rodopi.

Walter, R. 1993. Screenwriting: The Art, Craft and Business of Film and Television Writing. (trans.) Moscow: Institut povyisheniya kvalifikatsii.

Zhamsaranova, R.G. 2011. Концептосфера средневековой монгольской этнонимии [The concept sphere of Mongolian medieval ethnonymy]. PhD diss., Tomsk State Pedagogical University, Tomsk.

"Бегемот" - “Аевиафан” по-китайски [Behemoth is the Chinese Leviathan]. 2016. South China Insight News, January, 22. http://www.south-insight.com/node/217957 (accessed August 6, 2017). 